\title{
RESEARCHARTICLE
}

\section{Seed Potato Production Business through a Gender Lens}

\author{
Etiang Joseph*, Rose Mwesige, Sarah Kyarisiima, Ambrose Aheisibwe, Kwikiriza \\ Gerald, Ronald Muhereze, Ronald Ayahura Kutesa, and Alex Barekye
}

Kachwekano Zonal Agricultural Research and Development Institute, Kabale, Uganda

\begin{abstract}
Potato (Solanumtuberosum) is an important crop in highland areas of South Western and Eastern Uganda. Seed potato business is a key input for increasing potato productivity and contributes to people livelihood. Attempts to increase seed potato production and its contribution to livelihoods of men and women have not addressed a gap in seed demand and on its contributions to incomes of the farming households. Seed producers and research provides $0.15 \%$ of the total seed potato required. This has partly been attributed to lack of involvement of men and women in seed potato production business, leading to low yields averaging $7.5 \mathrm{t} / \mathrm{ha}$. This research aimed at finding out factors affecting involvement of men and women in seed potato business. Questionnaires, focus group and individual interviews of key informants were conducted involving men and women selected from 3 different locations. Results indicated that men are more involved in seed potato production, own more capital resources, and are mostly head household giving them an upper hand in decision making. Most men tended to engage in key activities leading to preparation for marketing. This gives them an opportunity to negotiated for market prices, sell and receive cash on behalf of their wives. Women tended to concentrate in domestic responsibilities such as feed the family. Women refrained from engaging in key activities in the seed potato business, which undermines the benefits that accrue to them.
\end{abstract}

Open Access

Citation: Etiang, J, Mwesige R, Kyarisiima S, Aheisibwe A, Gerald $\mathrm{K}$, Muhereze R, Kutesa RA, Barekye A. Seed Potato Production Business through a Gender Lens. Gender and Women's Studies. 2019; 2(2):5.

Received: June 06, 2018 Accepted: April 03, 2019 Published: April 19, 2019

Copyright: $\odot 2019$ Etiang J. This is an open access article distributed under the terms of the Creative Commons Attribution License, which permits unrestricted use, distribution, and reproduction in any medium, provided the original author and source are credited.

Corresponding author: Etiang Joseph, Kachwekano Zonal Agricultural Research and Development Institute, Kabale, Uganda

E-mail: joerets@gmail.com

\section{Keywords}

Gender, Constraints, Opportunities, Seed-potato, Production, Participation

\section{Introduction}

\section{Background}

Potato is a crop of major economic importance worldwide (FAO, 2008). It is the third most important food crop after rice and wheat (CIP, 2014). It is a major food and income crop in high land areas of Uganda where South West Highland Agro-ecological Zone (SWHAEZ) is part. However, farmers are faced with inadequate seed potato (tubers used for planting) to meet the high demand. The inadequacy of seed potato makes seed potato business very key for improvement of potato production in the zone. This has been attributed to low average yields ( $7.5 \mathrm{t} / \mathrm{ha}$ ) as opposed to $40-60 \mathrm{t} / \mathrm{h}$ attainable in other developed countries (FAO, 2013). It has also been due to lack of engagement of men and women in seed potato business, creating gender related issues that limit maximum production. In a paper on gender role in production and management it was noted that women contribute $90 \%$ of the labour force in Agriculture particularly in hoeing and weeding (Ogato et al., 2009; Jiggins, 1989). Irrespective of the enormous work done by women they are negatively affected by the low yields and low incomes obtained in potato growing business. The potato crop is produced by planting tubers referred to as seed potato. In most instances the tubers to be used toplant are first conditioned (kept in warm stores) till they sprout for a period of 2-3 month, hence referred to as seed potato. is sprouted. The tubers that are not sprouted but sold directly to the market are commonly referred to as ware potato. The involvement of men and women is key in that effort is maximised by all through the potato value chain and ensuring supply of quality and enough 
quantity to meet the demand. Seed potato production business is lucrative as compared to ware potato in the area due to the high prices offered for seed potato as opposed to low prized ware potato and involves all activities related to seed potato value chain. These activities stem right from land preparation, access to quality seed, planting, field management requirements, pest and disease management, storage and marketing of seed potato. As a business in the region those that participate in it improve their incomes and are able to address basic needs (Jiggins, 1989). However, by virtue of one being a man or woman the potato business has some influence depending on the societal assigned roles for men and women. Currently, seed producers and research institutions can only provide $0.15 \%$ of the required seed in the county (KaZARDI reports). Seed potato business is lucrative and attracts high prices as compared to ware potato and in the process those that get involved in seed potato take the benefits (CIP, 2011). Women tend to engage in ware potato, often utilized as food for the family and there is no way they get incomes from it.

The main challenges reported to affect seed potato production and sometimes affect seed potato business done by farmers are lack of capital, lack of quality seed, pests and diseases, low soil fertility and limited facilities required for seed potato production. These challenges have implication on men and women engagement in potato production. The constraints therefore have positive or negative influence in participation of men and women in seed potato production business. In addition are high prices of seed make farmers plant low quality seed from home saved seed (Aheisibwe et al., 2015). Attempts have been made to address some of these challenges, for example private sector has trained farmers on seed potato production business and facilitated some farmers to start up seed potato production and marketing business. In SWHAEZ alone 7 screen houses were established and are all managed by men with little involvement of women. Despite these attempts, there still exists a wide gap in terms of quantity and quality of seed potato produced and supplied to the market. The level of involvement of women in the seed potato business as compared to men is still low.It is reported that men and women's involvement in seed potato production business in SWHAEZ stands at $77.8 \%$ and $22.2 \%$ respectively (Low et al.,2015). It was observed that many reasons could have come into play as to why there is a gap in the involvement between men and women in seed potato production business.

Women's involvement was reported more in ware potato, which tied them to solely support household food security at the expense of increasing their incomes. If women are not empowered to actively engage in seed potato business, their income would remain low as compared to men. This then would reduce their contribution to household welfare are could lead to women becoming more dependent on men for livelihood. Besides their contribution to reducing a gap and seed potato demand will not be considered. It was therefore important to explore the role of men and women in seed potato production and factors influencing men and women involvement in the business. The study looked at the roles played, access to production resources, constraints encountered and available opportunities that ensure that men and women engage in seed potato business. The study was therefore designed to address the following specific objectives.

\section{Objectives}

To examine the roles played by men and women in seed potato production business in SWHAEZ of Uganda

To reduce gender based constraints and tap into opportunities that influence men and women participation in seed potato production business in SWHAEZ of Uganda

\section{Research Questions}

What engagements are preferred by men and women involved in seed potato business?

What are the concerns and opportunities that influence men and women participation in seed potato production?

What can be done to improve participation of both men and women in seed potato production business?

\section{Research Methodology}

\section{Description of the study area}

The survey was conducted in three districts of Kabale, Kisoro and Rubanda, located in the South Western Highland Agro-ecological Zone (SWHAEZ) of Uganda. This area is 
predominantly high altitude ranging from $1200 \mathrm{~m}$ to $2350 \mathrm{~m}$ above sea level. The area has agro-climatic conditions that favor a wide range of crop and livestock, as a major source of livelihood for the inhabitants (Wogoire \& Kashaija, 2008). The zone receives bimodal rainfall pattern ranging from $1000-1500 \mathrm{~mm}$ and temperature range is $10-30{ }^{\circ} \mathrm{C}$. The population density is about 300 persons $\mathrm{Km}^{2}$ and with population growth rate of $2.2 \%$, which has continued to exert pressure on land making it the most limiting resource in agricultural production. Chemining'wa et al., 2005 states that the soils in Kigezi are acidic to slightly acidic loams, reddish brown clay loams, humus loams and yellowish red clay loams with generally a good nutrient supply and with natural fertility and good drainage. The variations in cropping systems are result of the differences in agro-ecological conditions and socio-economic endowments within the districts in the zone. Potato is the main crop grown for food and incomes of the people (Bonabana-Wabbi et al., 2013). This is grown for various uses particularly seed for planting and ware for food processing into various products such as chips and crisps.

\section{Data collection and analysis}

In order to achieve the objective of the study, Qualitative and quantitative sex disaggregated data was collected among potato farmers using individual questionnaires, focus group discussions and key informant interviews. Acomprehensive questionnaire was used to collect quantitative data from 78 individuals, while men and women farmers were separately engaged in a focus group discussion to provide qualitative sex disaggregated data and any relevant information that influence activities of men and women in seed potato production and marketing business. In focus group discussions, participants were divided into two groups with men constituting one group and women another. The same checklist (set of questions) was administered to capture sex disaggregated data from the men's and women's group. In such a case women and men were separated in different groups to allow each category to provide information without fear. The information obtained in this manner was related to the men's or women's experience in seed potato business and was key to addressing challenges affecting each category. The results were reported basing on the views arising from individual interviews and group discussions conducted involving men and women. In addition, agroinput dealers were interviewed and their views were used to provide insights on to information obtained using other tools. Data was then compiled and analyzed using Excel spread sheets, summarized and presented in graphs and tables. The information obtained highlighted challenges that limit men and women in participating in profitable seed potato production and seek to learn from those that participate and are benefiting.

\section{Results and Discussion}

\section{Characteristics of the Respondents}

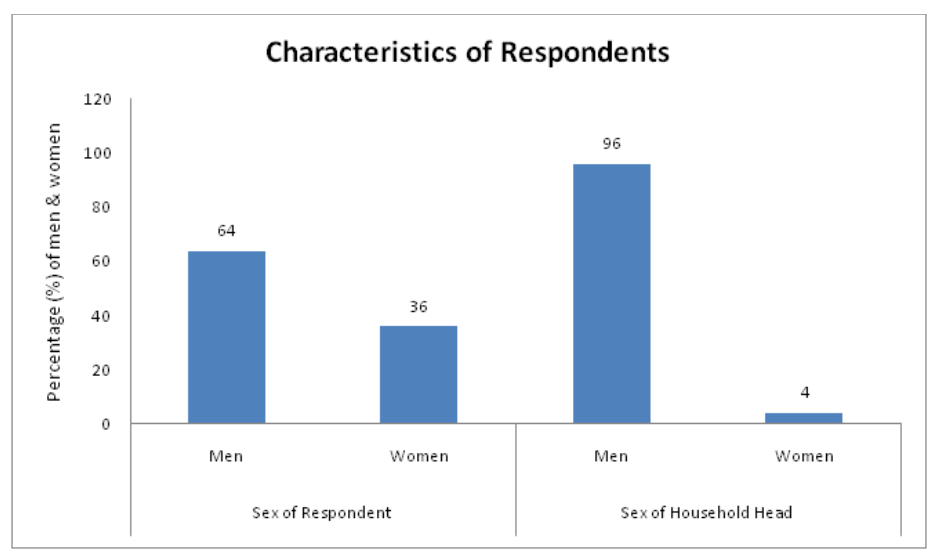

Figure 1. Showing characteristics of the Respondent by Gender

The $64 \%$ of respondents involved in the individual interviews were men and $36 \%$ women of which $96 \%$ of the men were found to be household heads as opposed to $4 \%$ of the women. In this area culture does not allow women to be household heads except those that become widows, those that buy own land and unmarried. This has implication on the decision making process, which in a household may involve a man alone, woman alone or jointly by a man and woman. Household heads usually influence decision making at all levels within the household, these may include decisions on land utilization, type of crop to plant, management 
of the crop and marketing of the products that accrue from such land. The final decisions made in such a community lies solely on the household head and this influences the level of participation of men and women in a vital business ventures for this case seed potato production business. The low number of women who are household heads makes it difficult for them to push forward decisions that address their challenges in seed potato business. It implies that their ability to engage and in profitable seed potato business is greatly affected.

\section{Roles of men and women in potato production}

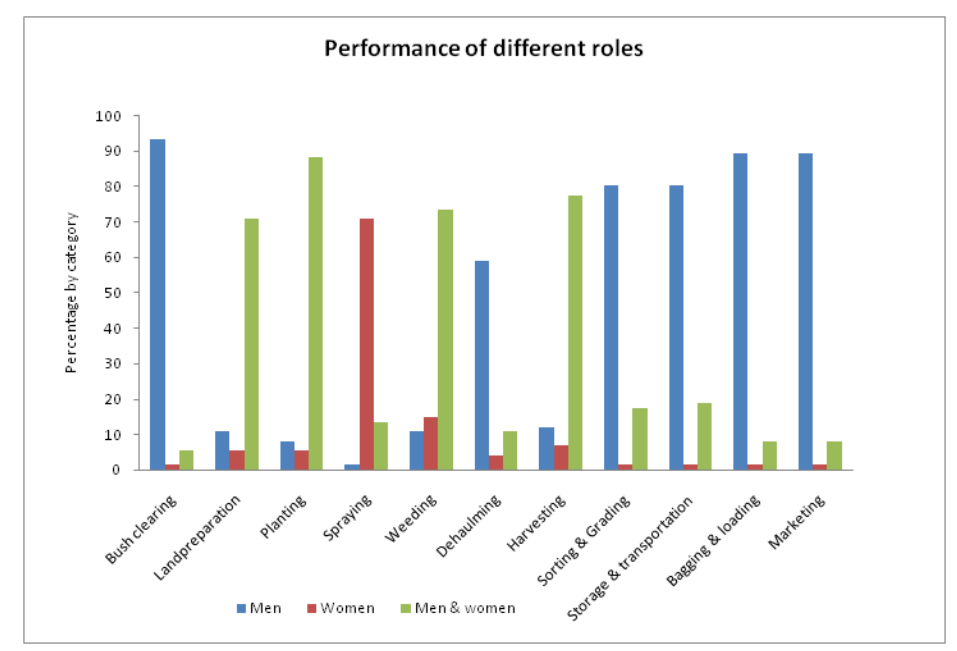

Figure 2. Showing performance of different roles in seed potato business

In categorizing men and women in separate groups, the roles preferred by each category to the other were determined. The results revealed that the roles assumed by men and women in seed potato business were observed in three categories, roles mostly done by men, roles mostly done by women and roles jointly done by both men and women. This means that all roles are done by either category but the level of involvement in such a role varied to some extent as defined by mostly and not solely. The roles mostly done by men were bush clearing contributing to (93.3 \%) as opposed to $(5.3 \%)$ and $(1.3 \%)$ both and women respectively. This is attributed to the nature of other activities that women are engaged and more so could as well depict the interest of men and women in the potato enterprise. This probably implies that the men are more interested in seed potato business and related activities as indicated by the level of involvement. When the crop is still in the field, men participating in dehaulming accounting to $(58.7 \%)$ as respectively opposed to $(10.7 \%)$ and $(4 \%)$ of the work done jointly and by women, making it an activity which is mostly done by men. After the crop has been harvested it was found that $(80 \%)$ of the work of sorting and grading is contributed by men with work done jointly contributing (17.3\%) and by women contributing (1.3\%). The study revealed that on transporting seed potato from the field after harvesting to the store men contributed ( 80 $\%$ ), women contributed (1.3\%) and (18.7\%) done jointly by men and women. On bagging and loading men $(89.3 \%)$, women $(1.3 \%)$ and $(8 \%)$ done jointly by both men and women. Marketing men contributed (89.3\%), women (1.3\%) and jointly done contributed to (8\%). The higher level of engagement on seed potato business by men puts them well ahead of the women irrespective of whether done jointly or by women alone. It is clear that in a seed potato growing household, activities where the majority of men highly participate are also done jointly. Implying that men take lead in these activities and women provide a supporting role. Roles mostly done by women included spraying with women contributing $(70.7 \%)$, jointly contributing (13.3\%) and men contributing (1.3\%) only. Weeding is contributed by both men and women in a household (73.3\%), as opposed to women $(14.7 \%)$ and men $(10.7 \%)$. When the crop has grown it was found that there were few men involved in disease control. Men moved to other roles leaving women to tend the crop at home. It was noted that most activities that were done jointly included land preparation $(70.7 \%)$, planting (88 \%), weeding $(73.3 \%)$ and harvesting (77.3\%). In the survey area there were more men (93\%) who did bush clearing than women. For land preparation, where high percentage of both men and women engage jointly in this activity could probably be due to the nature of land preparation in the zone. The activity is highly labour intensive done by use of a hand hoe due to steep terrain and requires joint effort to accomplish (Renu, 2008). The same applies to planting, the men and women do the activity together ( $88 \%)$ as the activity requires transportation of seed, digging of ridges 
and planting holes, so the men and women jointly cooperate (EIGE, 2016). On weeding the involvement of both was found to be high (73\%) reported that this activity is done by both in some households. This is attributed to the urgency to avoid the weeds choking the crop that is key for the household. Harvesting was mainly done jointly by the majority as reported by (77 $\%$ ) of those interviewed. After which, sorting, grading, bagging, transporting and marketing is mainly left to men. It therefore implies that men control the final revenue from the potato business in that from sorting, grading and bagging the produce is moved to the store and thereafter to the market. Probably this could be the cause of less involvement of women in seed potato business in the area. Despite those differences the household seems to do well when the activities are done jointly as opposed to men acting alone and women active alone. In this way they could cushion the limitation of each gender category and strive for improvement and the seed potato business will be improved.

Similar findings were observed under the focus group discussions conducted in two separate groups of men and women. The focus group discussion revealed an agreement in findings that men were more represented on seed potato businesses than the women. Although where they are represented they are allowed to take position of leadership. However the discussions exposed that even if the women are free to take position o leadership in such groups, men are most preferred them being more educated as compared to the women. It could also be due to the high level of responsibility on the shoulders of women which mostly includes household chores. Land is usually hired; owned and capital source is usually from credit obtained from the SACCOs. Other roles where women are found to shy away from are in spraying, de-haulming and management of the store houses. This is attributed to heavy engagement and the nature of the storage structures which are not friendly to the women outfit. The focus group discussion also reveled that both men and women recognize a need to have land, knowledge, quality seed and capital for additional inputs if one is to start seed potato business. However, access to credit required women to often seek permission to apply for credit from their husbands. This could influence the timing and the amount of credit as reported earlier in the individual interviews. On marketing, it was found that market information is obtained through phone calls / messages, extension workers, fellow farmers and radios. As noted earlier that men were involved in seed potato business than women, but those that are engaged benefit from the lucrative prices in the market and they are able to acquire more assets such as stores capital and housing to expand on the production. However, challenges on the access to agro-inputs were noted during the focus group discussions and these challenges were noted and verified during the discussions with the agro-input dealers considered as key informants in this study.

In this study agro-input dealers revealed that potato business requires lot of inputs which include, fertilizers, fungicides, sprayers, hoes, strings and polythene bags. These are obtained from agro-input shops, most of which were owned by men. In these agro-input shops, men are involved in purchases and lifting of goods during loading and offloading. In shops where women are involved they are engaged in sales, cleaning and organizing the items on display. Most agro-dealers interview observed that women tended to be honest than men when employed in such shops as sales persons. The challenges faced by the agro-input dealers were high cost of inputs, high competition, seasonality of the business, inferior products in the market and damage during transportation. 
Gender concerns affecting men and women participation in seed potato business Access to credit and major decision making by gender

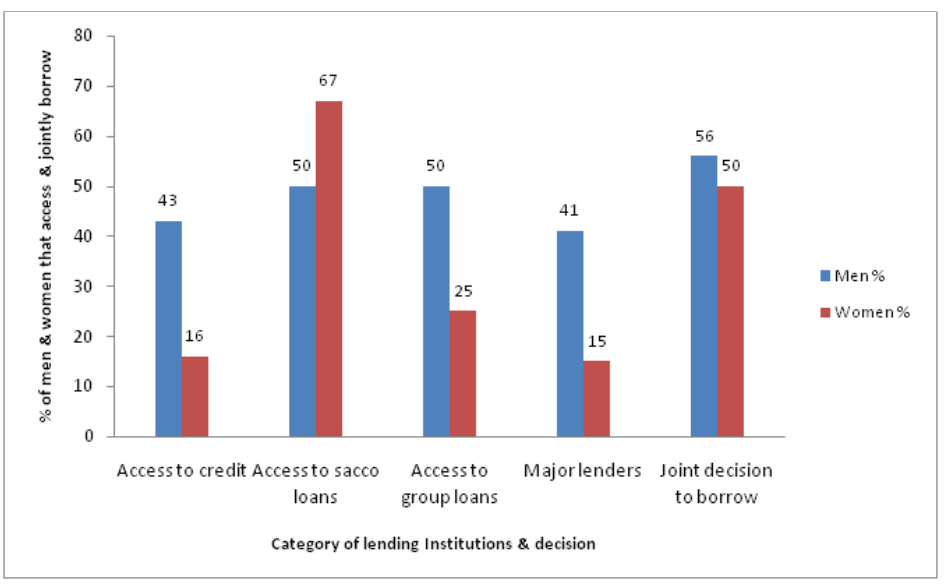

Figure 3. Access to credit facilities and major decision making

The findings revealed that various constraints affect participation of men and women in seed potato production. One of such constraint is access to agricultural credit to facilitate acquisition of production tools and equipment. The access to credit, the type of credit provider and the nature of decision made to borrow are all crucial in access to credit facilities for seed potato business. It was found that $43 \%$ of the men interviewed had reported having access to credit. This implies that $57 \%$ of the men in the group reported having lack of access to credit to support seed potato business. Among the women, it was found that the level of access was much lower with only $16 \%$ of the women reporting having access to credit to support seed potato business. This eventually puts them down when it comes to seed potato business that would require more capital to invest hence leaving them with the only option to shun the business. Much as men's group reported higher access to credit, it was less than $50 \%$. Implying that seed potato business is greatly affected by lack of access to sufficient credit facilities and this is in agreement with the findings of (Fletschner \& Kenney, 2014). It also indicates that men have an advantage on access to credit than the women and therefore are able to acquire seed potato production assets and undertake big investments as compared to women. This is in agreement with the findings of similar research where women investments in production were hampered by lack of assets and collateral (Olagunju et al., 2013). Probably in a situation where the two work together access to credit may improve as well for women as they will engage the men who have more collateral assets than them (Saito et al., 1994).

In addition, men's position as owners of capital resources, such as land that can be used as collateral, increases their access to credit. Of the $16 \%$ women who have access to loans $67 \%$ prefer getting loans from Savings and Credit Cooperative Societies (SACCOS) probably due to the ease of access, affordable amounts and favorable terms offered by SACCOS as opposed to Group loans and major lenders such as banks whose terms are stringent to meet by the local farmers. However in a household, where decisions to credit access are jointly made men and women equally accesses credit of $56 \%$ and $50 \%$ respectively. Possibly because of the government policy for example the Uganda land act 2010 makes spouses' automatic co-owners of land hence requiring their consent before family land can be sold or mortgaged. Perhaps with small amounts accessed in a SACCO arrangement, it limits the ability of women to engage in commercial seed potato business. This agrees with the findings of Fletschner \& Kenney, 2014 where the main factor that influenced women participation in production activities are the inability to borrow, failure to access financial services such as credit which could empower them to engage more and to make better life. Similar findings revealed that women do not own most of the assets; it becomes very difficult for them to provide collateral required by lenders. This is supported by (Saito et al., 1994) where women access to agricultural inputs and other agricultural support services such as land, viable financial services, cost effective extension advise in not proportionate with their role as farmers. The men tend to benefit from a wide range of credit providers and more so with bigger portfolio (Figure. 3). This could be attributed to their ability to provide collateral required by such bigger lenders and compared to small community lenders such as SACCOS. Therefore, if women are to be supported to increase their credit access then the focus should be to 
support SACCOS, which most of them borrow from and encourage joint decision making at household level. The low level of participation of women in seed potato business could as well be due to social norms and responsibilities that society assigns to women and such roles include domestic cores, low involvement in marketing, development activities and managing non-farm businesses. This is in line with the finding by (Hill \&Vigneri, 2014) where he observed that marketing and development are key in men and women participation in cash crops markets Women contribute more in food production and processing as men control productive resources and do more of farm decisions (Ogunlela \& Mukhtar, 2009).

\section{Access and ownership of facilities}

Table 1. Showing Ownership and access to production resources by men and women

\begin{tabular}{lcccc}
\hline Category & Men (\%) & Rank & Women (\%) & Rank \\
\hline Own large livestock & 35 & 9 & 25 & 9 \\
Ownership of small livestock & 42 & 7 & 32 & 8 \\
Ownership Farm Equipment & 33 & 10 & 21 & 10 \\
Ownership of non-farm equipment & 40 & 8 & 57 & 5 \\
Joint ownership of large livestock & 25 & 12 & 14 & 11 \\
Joint ownership of Small livestock & 46 & 6 & 43 & 6 \\
Joint ownership farm equipment & 63 & 4 & 68 & 3 \\
Joint ownership non-farm equipment & 28 & 11 & 39 & 7 \\
Access to large livestock & 60 & 5 & 43 & 6 \\
Access to Small livestock & 92 & 2 & 89 & 2 \\
Access Farm Equipment & 98 & 1 & 93 & 1 \\
Access Non-farm equipment & 40 & 8 & 57 & 5 \\
Access Storage facility & 79 & 3 & 61 & 4 \\
\hline
\end{tabular}

Results show that in men category (35\%) own large livestock (Cattle) compared to women $(25 \%)$ in their category. However, the number of men and women that do not own large livestock is higher implying that the capital base to support seed potato business is low among the majority of men (65\%) and women (75\%). In terms of ownership of the large livestock, men's category reported $25 \%$ of them jointly own the livestock. This implies that $75 \%$ of them know that the large livestock are not jointly owned. On small livestock (goats, sheep and Poultry) and farm equipment where $42 \%$ of men in their category own small livestock as compared to $32 \%$ reported in women's category. The nature of ownership is that in men's category $46 \%$ own small livestock as compared to $43 \%$ of women's category. On non-farm equipment, $57 \%$ in the women category owned it compared to $40 \%$ in men's category. The nature of ownership is that $63 \%$ of men reported joint ownership as compared to $68 \%$ of women. This suggests that women own more of non-farm equipment and this could dictate on roles and limit their involvement in seed potato business. It is in line with the finding of Kristjanson, 2014, observed that assets such as livestock are key to empowerment of women in Africa and Asia as it helps them increase their productivity. It therefore implies that strategies that increase women ownership of large livestock will enhance their capital and participation in agricultural businesses such as seed potato.

The men's reported having more access to large (60 \%) and small livestock (92 \%), farm equipment (98\%) and storage facilities (79 \%), while women reported having access to more of non-farm equipment (57 \%) than the men's category (40\%). The findings revealed that access to farm equipment was ranked first in the men's (98\%) and women's (93\%) category implying that irrespective of the ownership, access is to all the members of the household. This is in line with the finding of (Doss, 2014), where lack of ownership of resources affect participation of men and women in production. However, among men, the percentage that access farm equipment is higher than among women category. The implication is that the needs of men in terms of livestock, farm equipment and storage facilities used for seed potato business are addressed to a large extent than the needs of women. Livestock can be converted to support the business while the equipment boosts activities for production. Similarly, when women have non-farm equipment it means their engagement in seed potato business is reduced.

\section{Access and ownership of related production resources}


Potato production requires additional resources to enhance the production process and where this is not possible, the farmer becomes incapacitated (Jiggins, 1989). The main related resources for production of potato are land, advisory services, and stores for storage purposes. It is as well critical to own these resources as it reduces the cost of hiring in case one does not own. In this region it was noted that most of these resources are owned by men (Ogunlela \& Mukhtar, 2009), this reduces the level of engagement of women when they lack such resources and their use in a decision that solely does not rest on them. For example, without land one cannot cultivate, without extension advise production is low and without a store one cannot keep the produce to obtain good price. This leads to discouragement and failure for one to engage in such an enterprise.

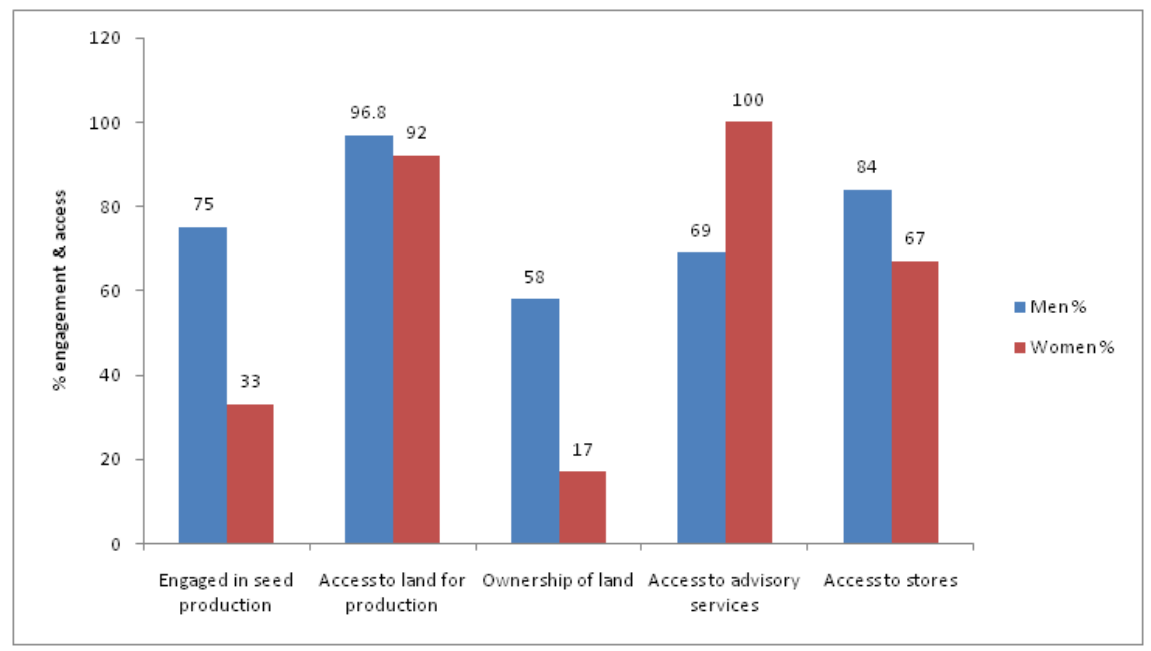

Figure 4. Showing level of engagement, access and ownership of resources and services

Men (75\%) are more involved in seed potato production than women who reported their involvement at $33 \%$ and this is due to many factors that limit women ability to engage fully. The women involved in seed potato business were found to access production resources and were able to benefit from the services and facilities provided to the community. Among the factors that probably affect involvement of other women is inadequate capital required for seed potato production. However, other factors observed were lack of ownership of land which stood at 17 $\%$ as opposed to the men's category that reported land ownership at $58 \%$. However irrespective of ownership of land, access was found to be by both men at $96.8 \%$ and women at $92 \%$ meaning that both have sufficient access to land for seed potato business. Ownership of land is critical when it comes to decision making process on use of such land but access is equally vital for a person engaged in seed potato business (Van den Bold et al., 2015). In a few instances where women owned land it was of very small acreage compared to their male counterparts. The same result was reported by Low et al., 2015, where African women managed to own only one percent of the land and had limited access to financial resources. Both men and women had access to advisory services, which is a good avenue to pass on technologies to farmer. Men and women therefore take on technologies that will suit their interest best even though this may influence the level of production and their participation in such activities. It was also revealed that more than $80 \%$ of men have access to storage facilities as seed business requires these facilities to allow seed to sprout. It implies that those without such facilities cannot engage in this business (Quisumbing et al., 2015). It was noted that access to advisory services was $100 \%$ among women's category than among the men suggesting that women probably tend to participate in advisory meetings than the men. In so doing they gain the knowledge but do not fully put it to practice due to other limitations. In addition, women were found to take full responsibility of feeding the household as a result even their ware potato in most cases was converted to food for the entire family. It therefore implies that women products are used to take care of the family leaving little for the market. For the men all the entire harvest is marketed this enable man to have more income that women. This is in line with findings of (Okanya \& Kroschel, 2014) on the gender disparities between men and women. In similar findings, (Kristjanson et al., 2017) reported differing needs between men and women, whom have to be taken into considerations at policy level if these needs are to be addressed. 
Table 2. Challenges encountered by men and women in seed potato business

\begin{tabular}{lrrrr}
\hline Challenge & Men \% & Rank & Women $\%$ & Rank \\
\hline Limited access to land & 38 & 1 & 66 & 1 \\
\hline Home disagreements & 8 & 7 & 3 & 10 \\
\hline No group Membership & 6 & 9 & 7 & 7 \\
\hline Limited credit facilities & 2 & 12 & 21 & 4 \\
\hline Limited capital & 27 & 3 & 34 & 2 \\
\hline unfavorable weather conditions & 19 & 5 & 3 & 10 \\
\hline Degraded soils & 2 & 12 & 0 & 0 \\
\hline Pests and diseases & 33 & 2 & 31 & 3 \\
\hline Limited access to quality seed & 25 & 4 & 21 & 4 \\
\hline Fake Agro-inputs & 6 & 9 & 3 & 11 \\
\hline Not trained in seed production & 8 & 7 & 7 & 7 \\
\hline Lack of storage facilities & 17 & 6 & 17 & 6 \\
\hline Seed potato converted to food & 0 & 13 & 3 & 10 \\
\hline Limited extension & 4 & 10 & 7 & 7 \\
\hline High cost of Agro-inputs & 4 & 10 & 0 & 0 \\
\hline
\end{tabular}

The major challenge limiting men and women in seed potato production are limited access to land for both men and women, but the challenge is reported nearly twice as much as women than men double for women: (65\% versus $37.5 \%$, respectively). This could be due to the position of respect the man holds in the family as a household heads and in most cases land belongs to them. Also when farmers were interviewed on whether men and women had equal access to production resources most of them said no and added that men had better access to land than women. This is in agreement with the findings reported by (Kristjanson et al., 2017). Other challenges include lack of capital (Men $27 \%$, women $34.4 \%$ ) limited credit facilities (2\% men, $20.6 \%$ women), pests and diseases, limited access to Quality seed and lack of storage facilities some of which were highlighted earlier in the discussion. Besides is low access to agricultural extension, which according to Ragasa, 2014 could influence participation of men and women in agricultural activities. In that study it was observed considering the gender of the extension workers and whether both men and women receive the extension messages. In the study it was noted that women tended to become conservative if an extension worker is of the opposite gender. On access probably women tended to attend meetings than the men although the women had more engagement at home. It is true that men were taken up with other business responsibilities that kept them away from home.

\section{Existing opportunities for seed potato producers}

Despite the challenges in engaging in seed potato business, a lot of opportunities exist for men and women farmers engaging in seed potato production. The biggest opportunity being the high prices offered for seed potato and the profits enjoyed by those engaged in seed potato business. With better prices as compared to other crops possibly of the same production costs, those involved benefit and are able to improve their livelihood faster than those not involved. Comparatively pricing between the ware potato and seed potato revealed that the seed potato had a price 30 percent higher than ware potato. The more the women get involved in seed potato business the more they get lifted up in poverty in the area. This is in agreement with findings of (USAID, 2010), where women were found to be excellent seed multipliers and this requires their capacity to be built. The existence of support from the Government of Uganda through Operation Wealth Creation programme provides agro inputs and extension services to the farmers. Quisumbing et al., 2014, as well reported the knowledge gap as one of the factors that could influence participation of men and women in agricultural business. Besides inputs from the National Agricultural Research Organization (NARO) is key for farmers to increase their productivity. Farmers can as well benefit from training opportunities and starter inputs provided by different development partners operating in the area. 


\section{Conclusions}

Generally, men and women are involved in seed potato business throughout the seed potato production business; however, their level of involvement varies basing on various factors that influence them. Men were found to assume final stage roles such as sorting, transporting, bagging, loading and marketing. In the process men tent to understand the details and can have an opportunity to make bargain in prices as women tend to shy away from such activities. It was found that men and women preferred to work jointly performing roles such as; land preparation, planting, weeding and harvesting the crop. Spraying was left for women to carry out, but at harvest it is done jointly. Men were found to be in a better position to access a wide range of credit from credit providers than women who could only afford access from village SACCOS. This puts them in an advantage to engage in seed potato business than women. In addition, men were found to have more access to farm equipment, land, stores and were found to be more engaged than women in seed potato business. The main challenges were limited land, limited capital, pests and diseases, limited access to quality seed, weather and inadequate storage facilities. It is therefore recommended that practices that involve both men and women be supported in a household. In situation where ownership of resources is vested on one category these be shared to encourage performance of the other category in seed potato business. Any move to increase access to credit facilities is highly recommended for success of men and women in seed potato business. It is also important that government works hand in hand with the private sector to address the needs of the farmers engaged in seed potato business, particularly using approached that address women challenges in the business.

\section{Acknowledgement}

This Research was undertaken as part of a training of Agricultural Scientists on Gender and Research, our gratitude to the National Agricultural Research Organization for giving us the opportunity to participate, GREAT leadership for the support and guidance they provided during the training and farmers who participated.

\section{References}

Aheisibwe A. R., Barekye, A., Namugga, P., \&Byarugaba, A. A.(2015). Challenges and Opportunities for Quality Seed Potato Availability and Production in Uganda, Uganda Journal of Agricultural Sciences, 16(2), $149-159$.

Bonabana-Wabbi, Ayo, J. S., Mugonola, B., Taylor D. B., Kirinya, J. \&Tenywa, M. (2013). The Performance of Potato Markets in South Western Uganda, Journal of Development and Agricultural Economics, 5(6), 225-235.

Chemining'wa, G., Mulagoli, I., Mwonga, S., Ndubi, J., Tum, J. (2005). Kabale Apples: Boom or Burts? A study to Develop Strategies to Exploit Market Opportunities for Apple Farmers in Kabale, Uganda. ICRA, Netherlands.

CIP. (2011). Roadmap for Investment in the Seed Potato Value Chain in Eastern Africa. Lima, Peru, pp.27.

CIP, (2014). Global Potato Research for a Changing World. working paper.

Doss, C. (2014). Data needs for gender analysis in agriculture. In Gender in Agriculture, Springer, Dordrecht, pp. 55-68.

European Institute for Gender Equality (EIGE), (2016). Gender in Agriculture and Rural Development. Retrieved from: http://eige.europa.eu/gender-mainstreaming.

FAOSTAT. (2013). Food and Agriculture Organization statistical database. United Nations, Rome, Italy. Retrieved From: http://www.faostat3.fao.org/home/index.html

Fletschner, D., \& Kenney, L. (2014). Rural women's access to financial services: credit, savings, and insurance. Gender in Agriculture, Springer, Dordrecht, pp. 187-208.

Food and Agriculture Organization of the United Nations (2008). International year of the potato [Online]. Retrieved from: http://www.potato2008.org

FAO, Retrieved from: http://faostat.fao.org/site/339/default.aspx 
Hill, R. V., \& Vigneri, M. (2014). Mainstreaming gender sensitivity in cash crop market supply chains. In Gender in Agriculture, Springer, Dordrecht, pp. 315-341.

Jiggins, J. (1989). How poor women earn income in sub-Saharan Africa and what works against them. World Development, 17(7), 953-963.

Kristjanson, P., Waters-Bayer, A., Johnson, N. L., Tipilda, A., Njuki, J., Baltenweck, I., ..., MacMillan, S. (2014). Livestock and women's livelihoods. In Gender in Agriculture, Springer, Dordrecht, pp. 209-233.

Low D.C.M., Roberts, H., \& Whiting, R. (2015). Board gender diversity and firm performance: Empirical evidence from Hong Kong, South Korea, Malaysia and Singapore. Pacific-Basin Finance Journal, 35, $381-401$.

Kristjanson, P., Bryan, E., Bernier, Q., Twyman, J., Meinzen-Dick, R. S., Kieran, C., ..., Doss, C. (2017). Addressing gender in agricultural research for development in the face of a changing climate: Where are we and where should we be going? International Journal of Agricultural Sustainability, 15(5), 482-500.

Ogato, S., Boon K. E., \& Subramani, J. (2009). Gender roles in crop production and management practices: A case study of three rural communities in Ambo district, Ethiopia. Kamal-Raji. Journal of Human Ecology, $27,1-20$.

Ogunlela, Y. I., \& Mukhtar, A. A. (2009). Gender issues in agriculture and rural development in Nigeria: The role of women, Humanity \& Social Sciences Journal, 4(1), 19-30.

Okanya, J.S., \& Kroschel, J. (2014). Gender differences in access and use of selected productive resources among sweet potato farmers in Uganda. Agriculture \& Food Security, 3, 1.

Olagunju, F. I., Fakayode, S. B., Babatunde, R. O. \& Ogunwole-Olapade, F. (2013). Gender Analysis of Sweet Potato Production in Osun State, Nigeria. Agricultural Economics and Extension.

Quisumbing, A. R., Rubin, D., Manfre, C., Waithanji, E., van den Bold, M., Olney, D., .., Meinzen-Dick, R. (2015) Gender, Assets and Market-oriented Agriculture: Learning from High-value Crop and Livestock Projects in Africa \& Asia. Agriculture and Human Values, 32(4), 705-725.

Quisumbing, A. R., Meinzen-Dick, R., Raney, T. L., Croppenstedt, A., Behrman, J. A., \& Peterman, A. (2014). Closing the knowledge gap on gender in agriculture. In Gender in Agriculture, Springer, Dordrecht, pp. 3-27.

Ragasa, C. (2014). Improving gender responsiveness of agricultural extension. In Gender in Agriculture, Springer, Dordrecht, 411-430.

Renu, J. (2008). Participation of Farm Women in Potato Production. Indian Research Journal of Extension Education, 8(1).

Saito, K., Mekonnen, H., \&Spurling, D. (1994). Raising the Productivity of Women Farmers in Sub-Saharan Africa (Discussion Paper 230). Washington, DC: World Bank.

USAID. (2010). Feed the Future EastAfrica FY 2010 Implementation Plan. Washington, DC, pp. 48.

van den Bold, M., Dillon, A., Olney, D. K., Ouédraogo, M., Pedehombga, A., \& Quisumbing, A. R. (2015). Can integrated agriculture-nutrition programmes change gender norms on land and asset ownership? Evidence from Burkina Faso. The Journal of Development Studies, 51(9): 1155-1174. 